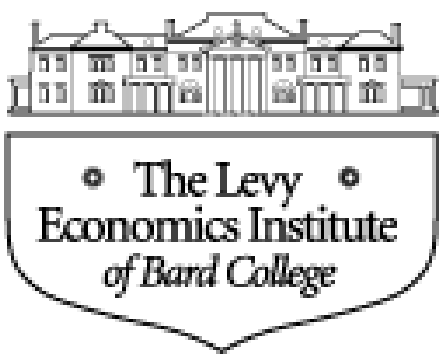

Working Paper No. 445

\title{
A Random Walk Down Maple Lane? A Critique of Neoclassical Consumption Theory with Reference to Housing Wealth
}

\author{
by \\ Greg Hannsgen \\ The Levy Economics Institute of Bard College \\ hannsgen@levy.org
}

April 2006

The author thanks Philip Arestis and L. Randall Wray for very valuable comments. They are not responsible for any errors.

The Levy Economics Institute Working Paper Collection presents research in progress by

Levy Institute scholars and conference participants. The purpose of the series is to disseminate ideas to and elicit comments from academics and professionals.

The Levy Economics Institute of Bard College, founded in 1986, is a nonprofit, nonpartisan, independently funded research organization devoted to public service. Through scholarship and economic research it generates viable, effective public policy responses to important economic problems that profoundly affect the quality of life in the United States and abroad.

The Levy Economics Institute P.O. Box 5000

Annandale-on-Hudson, NY 12504-5000

http://www.levy.org

Copyright (C) The Levy Economics Institute 2006 All rights reserved. 


\begin{abstract}
The development of the permanent income/life cycle consumption hypothesis was a key blow to Keynesian and Kaleckian economics, and, according to George Akerlof, it "set the agenda" for modern neoclassical macroeconomics. This paper focuses on the relationship of housing wealth to neoclassical consumption theory, and in particular, the degree to which homes can be treated collectively with other forms of "permanent income." The neoclassical analysis is evaluated as a partly normative and partly positive one, in recognition of the dual function of the neoclassical theory of rationality. The paper rests its critique primarily on the distinctive role of homes in social life; theories that fail to recognize this role jeopardize the social and economic goods at stake. Since many families do not own large amounts of assets other than their places of residence, these issues have important ramifications for the relevance of consumption theory as a whole.
\end{abstract}

JEL Codes: A130, B400, B500, E210

Keywords: Consumption theory, theories of rationality, positive/normative distinction, liquidity constraints 


\section{INTRODUCTION}

In the world of consumption theory, certain themes have persisted since at least the early 20th Century. Neoclassical economists certainly have mounted a formidable assault on Keynesian theory, but their thought is highly influenced, not just by new techniques, but also by the work of Irving Fisher and other capital theorists of the late 19th and early 20th centuries.

Fisher and other economists of his time developed real theories of consumption that emphasized substitution of consumption across time periods. By contrast, one of Keynes's chief contributions to economics was to develop a theory in which consumption was largely a function of current income. Around the same time, Michal Kalecki developed models in which, as he put it, "workers spend what they get, and capitalists get what they spend," implying a world in which the vast majority of individuals lived on a paycheck-to-paycheck basis.

Modern theorists of consumption attribute their theories to Milton Friedman (1957) and Franco Modigliani and Richard Blumberg (1954), rather than to Fisher. ${ }^{1}$ Both of these writers sought an accommodation between Keynesian thought and the more traditional theory of Fisher and others. And for Friedman in particular, his contribution to consumption theory was a conscious effort to effect a counterrevolution against Keynes. Specifically, he argued that his theory, in which consumption was a function of permanent income, including the annuity value of future income flows, showed that the Pigovian real balance effect could save capitalism from recession in the absence of government intervention: in a deflationary environment, the inflation-adjusted value of money holdings ("real balances") would increase. Since, in Friedman's consumption theory, consumption depended on the stock of wealth, rather than current income, the "real balance" effect could help consumption expenditures recover spontaneously in a deflationary environment $(1957$, p. 5). Hence, discretionary policy might not be needed.

Friedman's theory also called into question the effectiveness of fiscal policy. Keynes argued that government budget deficits would have a multiplier effect, because consumers would use money from tax cuts or government programs to boost their spending; and those on the receiving end of these expenditures in turn increased their own consumption spending. Keynes's argument that budget deficits would have a large stimulative effect on the economy would not hold, according to Friedman, if consumption were largely a function of total wealth (or permanent income), not income. Only a small percentage of any tax cut, for example, would 
be spent, because most of it would be put in the bank or securities to finance future consumption (except when the tax cut was permanent). In a word, the marginal propensity to consume out of current income, in Friedman's world, would be relatively small.

Clearly, for Friedman, as for Keynes and his followers, the stakes in the battle over the "consumption function" were large, and George Akerlof does not exaggerate when he says that Friedman's consumption theory "set the agenda for modern macroeconomics" (2005). In this paper, we focus on a particular element of the Friedman-Modigliani consumption theory: the role of housing wealth.

This article concentrates in particular on the consumption theories that derive from Friedman, Modigliani and Blumberg, and less directly, Fisher. To varying degrees, neoclassical consumption theorists treated all assets as fungible: they all counted equally as part of a homogeneous mass called wealth. They suggested an ideal form of housing market in which houses were as liquid as securities. Changes in housing wealth in this theory have the same effects on consumption as changes in other parts of consumers' portfolios. We wish to argue for

keeping housing distinct from other assets and against making houses completely liquid. As we see it, this separation of housing is not merely an empirical hypothesis to test; it has normative implications that could lead to a rethinking of many policy developments that have taken place over the past 30 or so years. If people have a tendency to draw a distinction between forms of wealth, maybe they have good reasons for doing so. In stressing consumers' feelings that they should treat their housing wealth in a particular way, this paper follows the line of thought of Akerlof, who has argued that consumers" "shoulds" have an important effect on their consumption behavior (2005). This paper therefore proposes a sketch of an alternative set of norms and institutions for valuing homes.

\section{ARE HOMES A COMMODITY LIKE ANY OTHER?}

Many recent authors have developed theories of the heterogeneity of goods, and these theories have been applied to many areas, including cost-benefit analysis and the ethics of surrogate motherhood (Anderson 1993). Elizabeth S. Anderson and other philosophers have argued that certain goods are intrinsically different from others and should therefore be produced, distributed, and consumed in different ways. This line of work stands in sharp contrast to 
economic theories of rationality, which reduce all goods to utility and make no distinction between market and nonmarket goods.

We seek to apply this sort of analysis to homes. Here we do not deny that houses are market goods but rather assert that they are different in kind from other market goods. ${ }^{2}$ Therefore, they should be and are treated differently by consumers. More to the point, they should be treated differently from the way neoclassical consumption theory suggests. Specifically, the norms, institutions, and behaviors surrounding the production, maintenance, and exchange of homes (which is an example of what Anderson (1993) calls a "mode of valuation") should not be as neoclassical consumption theory prescribes. We draw the conclusion that neoclassical theory has misplaced the role of one of the largest purchases most families will make in their entire lives. Further, it will be argued that a correct understanding of the nature of the goods provided by houses has important implications for policy.

The arguments of Anderson and others generally proceed by observing the distinctive aspects of a particular good. To point out certain special qualities about housing wealth, we contrast it with a prototypical financial asset. This reference-point asset will be a bond issued by a Fortune-500 company. A bond is also clearly tradeable in a deep and liquid market, representing a stark contrast with homes. This reason for this particular choice of a contrast to housing wealth will become evident later.

One key feature of homes is that, in contrast to bonds, they usually cannot be alienated without effect on a family or individual's social existence. This is true in several respects. First, a homeowner and his or her family members socialize with their neighbors, go to the same schools, share valuable information about jobs, and often "look out for one another." This fact makes the decision to sell a home a very profound one, compared with the choice of switching from one bond to another. Many people are deeply aware of this, and many Americans remember childhood moves as traumatic events. In any event, for children, a move can mark the transition literally from one phase of life to another. Regular moves are a part of many children's lives, but they still have an important impact.

A second social implication of the sale of one's home is in its role as a status symbol. Generally, the more visible a good is, the more important this role is. One rarely compares insurance policies or bonds with envy or pride, especially with regard to their individual qualities. A home, on the other hand, is clearly part of the public visage presented to the community by a family. Just as many people adjust their expressions as they prepare to knock 
on a door, they feel an obligation to present themselves in a way that is socially acceptable and honored (Goffman 1959).

A sense of control is a third social advantage of homeownership (Rohe, Van Zandt, and McCarthy 2002). Homeowners may alter their properties as they see fit. They can control who enters their property to a greater extent than renters can. They can set their own rules about pets, etc. These can be regarded as social benefits because they amount to an improvement in one's autonomy vis-à-vis other individuals.

Some other differences stem from the fact that individual bonds are only a small portion of their owners' portfolios. In most cases, no one company to which one has lent money commands more than a fraction of one's time. (This does contrast with small enterprises and the entrepreneurs who often own them.) But Federal Reserve data show that homes make up over half of the median American household's assets. Most people cannot diversify away any risk arising from owning their place of residence.

The relative importance of the family home in one's portfolio leads to several consequences. One is that the homeowner takes a great interest in events that affect his or her property values and "neighborhood quality." This implies that homeownership carries with it political and social involvements that cannot easily be separated from legal title to the property. One way of looking at the commitments that come with ownership is through the notion of "exit" and "voice." The typical owner of a bond will simply sell it if he or she believes the company is making poor decisions, whereas, partly because of the illiquidity of homes, the homeowner must resort to "voice" — working to change things for the better, rather than leaving when signs of trouble appear.

Another contrast with nonhousing wealth lies in the pride (another partially social phenomenon) associated with a particular dwelling. Many homeowners spend large amounts of time improving and maintaining their properties. They are able to fix them up in ways that reflect their own personalities and needs. Hence, homes are often taken to reflect their owners' personalities and character. As a result, owners take great pride in the homes. Moreover, this sort of pride cannot easily be transferred to another home cared for and built up by a different owner. A family often recognizes its home as "our" enterprise, reflecting a personal connection not applicable to bonds. 
Closely related to the issue of individual pride is the notion that goods such as houses assist families in asserting and communicating an identity. In a world in which the wealthy are free to adopt a variety of lifestyles, a house makes a statement about the sort of family or individual that the residents would like to be. With a home comes not only stability, but also the symbolism of stability, of being a pillar of one's community (Coşgel and Minkler 2004; Starr 2004).

As consumers of housing create social identities, they also publicly affirm certain sociocultural values (Dolfsma 2004). A purchaser of a home is seen as valuing autonomy, privacy, and family, in contrast to the more youthful, mobile, and fast-paced ideals of the urban apartment-dweller.

For many individuals, an old house offers sentimental values that cannot be reproduced like other commodities. Many old people are reluctant to leave their homes and choose to stay in them even when health or finances would otherwise force them out. ${ }^{3}$

In all, homeowners are attached to their properties in a number of ways. In some cases, the attachment is to homeownership in general, but in others, homeowners are bound to their particular dwelling. In both cases, the sale of a house carries with it certain social and personal implications that do not come into play when a bond is sold. Later in this paper, we discuss some possible implications of the special role of homes for the way we should value, produce, maintain, and exchange places of residence.

\section{ECONOMIC THEORIES AS PORTRAITS AND AS TEMPLATES}

The argument of this paper rests upon certain methodological foundations. Empiricists tend to think of models as representations of the world that are more or less accurate. On this view, it would make little sense to argue against a theory on the grounds that it misled people on the best way to act. This paper adopts a different view: that in social science, theory can affect the world as much as the world can affect theory (Schwartz 1986). For example, Adam Smith's work was as much a blueprint, or prescriptive ideal, for a free-market system as it was an actual rendering of the economy as it existed in Smith's time. Another demonstration of the validity of this view of theory is recent findings that economics students see moral and business problems in different ways than "naïve" subjects, and presumably behave differently as a result. Students in economics classes apparently learn not only how others act but also draw conclusions about 
how they, the students, should act. As another example, Friedman's monetarism was largely a prescription for monetary control, and not merely a theory of macroeconomic history. These three cases show that social scientific theory is not merely a reflection of an independent, fixed reality.

How does one evaluate theory on this view? Clearly, since theory can be a self-fulfilling prophecy of sorts, one cannot judge certain types of theory based on its correspondence with the "real world," in the sense of a literal matching of theory with fact. It is hardly surprising that actual society can be empirically matched with its own blueprint. One can however, judge whether the blueprint has wrought desirable results and whether it leads to a sense of understanding, rather than confusion and a sense of helplessness. And an alternative normative theory may also function as a positive theory.

An alternative way of viewing the process of theory justification in the absence of decisive empirical tests involves studying the benefits of various kinds of market and nonmarket goods and how they are best obtained. Such an investigation may lead to the adoption of particular "modes of valuation," or sets of norms and practices that allow particular benefits to be gained (Anderson 1993; Schwartz 1986). As an example, one might argue that one of the goods or benefits associated with baseball is the excitement that comes with close, low-scoring games. This might lead to the conclusion that the rules of the game should not be manipulated so as to increase the number of home runs.

On this view, just as correspondence does not imply good theory, a failure of correspondence is not a damning feature. One might study the nature of houses and decide that they are best traded on highly liquid markets and treated like any other good. In that case, the finding that current practices do not permit the easy liquidation of house wealth does not speak against the theory. If the empirical world does not match the theory, one would argue, then so much the worse for the empirical world. A failure of correspondence would simply indicate that much work needed to be done to help the real world catch up with the ideal represented by the theory.

Hence, in this paper, we regard the neoclassical theory of consumption as a prescriptive blueprint for an economy with liberalized financial markets. We investigate the degree to which the theory has been faithfully implemented (for example, in financial deregulation legislation) and to which other, alternative theories guide people's practices. We investigate whether the implementation has led to the results promised by the theory and whether certain flaws in the 
current system can be traced to theory. Since the theories of capital markets and consumption cover vast areas of economic life, we focus here on housing assets, specifically homes that are used as primary places of residence.

\section{IMAGES OF HOMOGENEITY AND LIQUIDITY: DWELLINGS AS “CAPITAL”}

What are the primary principles of neoclassical economic theory, as they apply to the role of housing assets? Wealth is reduced to one number, and there are rules for how that number changes when wealth is passed from time period to time period or consumed, resulting in rules of conservation and change across time. ${ }^{4}$ Friedman emphasizes that human wealth is not always liquid, so that someone with human wealth but few other assets could be liquidity constrained. But since all other assets are treated equally in Friedman's theory, his readers would not expect particular forms of nonhuman wealth to be particularly illiquid or subject to a special marginal

propensity to consume. This feature of neoclassical theory is crucial because housing makes up the vast majority of wealth for households. If neoclassical economists were to argue that they never intended houses to be equivalent to other forms of wealth, their case for permanent income theory is seriously weakened, as for most families, there would be few assets outside of houses to which the theory would apply. Hence, there would be few opportunities for the kind of intertemporal substitution emphasized by neoclassicals.

Modern day developments of Friedman's theory depart from the original in many ways. For example, they include rational expectations of all future income flows, whereas Friedman viewed permanent income as simply what the consumer regarded as his or her average income over a relatively short period of time. For reference later on, we describe a modern-day version of Friedman's theory here.

The key equation of permanent income theory says that one sets one's marginal rate of substitution between consumption in two different periods equal to the objective rate at which the economy allows such tradeoffs. The well-known "Euler equation" that purportedly demonstrates this is

$\mathrm{U}^{\prime}\left(\mathrm{C}_{\mathrm{t}}\right) /\left(\mathrm{U}^{\prime}\left(\mathrm{C}_{\mathrm{t}+1}\right)\right)=(1+\mathrm{r}) \beta$ 
This is where $\mathrm{U}()$ is the function giving utility in any one period as a function of consumption in that period, $(1+r)$ is the gross real interest rate, and $\beta$ is the discount factor that tells us how much we weight future utility as against present utility. (We abstract from uncertainty and risk regarding future variables, a highly problematic issue in theories of this type.) This equation is analogous to the micro equality of the ratio of marginal utilities of two goods to the ratio of their prices. The upshot of the equation is that one increases one's savings for the next period up to the point in which one additional dollar of saving is worth the same as an additional dollar of current consumption (Obstfeld and Rogoff 1996, p. 3).

What sort of role would these theories prescribe for housing, the issue in this paper? It would be a form of wealth like any other and could be easily liquidated, either through sale or through home-equity borrowing. As a result, it could be added on to other forms of wealth to calculate permanent income. It would then be assumed that agents consumed their housing wealth in exactly the same way as their other holdings: by treating total wealth as an annuity, to be drawn down regularly according to the imperatives of marginal satisfaction in each period (Thaler 1990). Housing would also be analogous to all other forms of wealth in that one would be able to diversify away one's holdings to some extent by borrowing against one's home to purchase another investment. We can sum up the treatment of housing wealth by two phrases: the homogeneity thesis, which means that in making economic decisions, housing wealth is (or should be) considered as equivalent to financial assets and other forms of capital (except perhaps because of the "consumption flows" yielded by houses) (for related ideas, see Mirowski 1989); and the liquidity thesis, which holds that it is (or should be) no more difficult to access, borrow against, finance, and trade housing wealth than it is to withdraw money from a bank account.

So, we have argued that modern neoclassical theory prescribes a certain ideal world, in which capital markets are "perfect," and homes are part of those markets, like any other form of wealth. In short, neoclassical economics asks us to accept a world in which homes are very much like bonds. Is this world coming into existence now? Is the blueprint of neoclassical financial markets being followed? Some economists have argued that with the increasing availability of credit, and in particular home equity credit, liquidity constraints are being broken down, with the observable result that consumption is increasingly a function of permanent income. It is therefore important to study the evolution of the institutions of housing finance in the United States. 


\section{THE GROWTH AND MARKETIZATION OF HOUSING FINANCE}

The history of housing finance can be read as a steady march toward "perfect" capital markets. In accordance with the homogeneity thesis, subsidies, interest rate regulations, and barriers to competition have been reduced over the past 30 years, resulting in a system in which homeowners, potential and existing, can borrow against housing wealth at a low, marketdetermined rate. Securitized housing loans are now traded on markets like commodities or the obligations of businesses, resulting in a deep, liquid market. Investors make tradeoffs between housing assets and other forms of investment as easily as they move money from stocks to bonds. Transactions costs of home-equity loans are lower than ever. These developments are related to the liquidity thesis for homeowners, as developments in secondary markets affect the ready access of homeowners to the equity in their homes. All of this history has implications for the validity of neoclassical consumption theories, so they are worth exploring in some detail.

Several features characterized mortgages before they became the instrument for consumer borrowing that they are today. Housing policy in the United States until some time from 1970 to 1980 was a legacy of the New Deal. Prior to that time, long-term mortgages were not widely available. Homeowners carried mortgages that were due in full within a relatively short period. Mortgages often were for only 50 percent of the purchase price of the home. In the Depression, because of the weak state of personal income and the banking system, many people were unable to find the new loans that were necessary to meet "balloon payments" due at the end of the term of a mortgage. This vulnerability led to widespread defaults, which burdened consumers and threatened the solvency of the banking system.

The New Deal reforms sought to prevent this sort of crisis from ever happening in the future. The Federal Housing Administration and the Veterans' Administration were charged with guaranteeing home mortgages, allowing the development of the long-term mortgage. Though these agencies did not guarantee all mortgages, they were highly influential in the rapid spread of the 20-year mortgage.

The VA and FHA programs were subject to several flaws from the beginning. The term "redlining" was born in the early years of the FHA, as bureaucrats outlined areas on maps in red ink that would not benefit from their loans. Also, it was primarily relatively well-off Americans who benefited from FHA loans: the greatest share of loans went to households earning $\$ 2,000$ to $\$ 2,500$, while the median income was below \$1,500 (Fishback, Horrace, and Kantor 2001, p. 3). 
But, there is little argument among experts that these programs allowed many members of the white middle class to afford homes that otherwise would have been out of reach. For better or worse, the FHA and VA helped create modern suburban America, as homeownership rose from 44 percent of all households in 1940 to 65 percent in 1976 (Colton 2002, p. 7). Title I of the act that established the FHA provided for guaranteed loans for home improvements, further stimulating the housing industry.

Several features of the FHA began to change around 1975, though. First, the FHA had declined in importance compared to what are now known as Fannie Mae and Freddie Mac, which specialized in bundling mortgages into securities (Kaserman 1978). These entities, which eventually became profit-making enterprises, were a large factor in turning mortgage capital into a homogeneous, tradeable commodity.

Also, around the same time, savings and loans became subject to market forces. Previously, they paid interest rates that were capped by law, and confined their assets primarily to home mortgages. The savings and loans benefited greatly from the cheap money they obtained from small depositors and the guarantees offered by the federal government. As a result, the savings and loans entered a relatively tranquil period, with few runs or bankruptcies. The housing finance "market" remained "segmented" from the rest of the capital markets, and this separation may have fostered stability.

But policymakers began to see this protected status as an inefficiency. The neoclassical notion of perfect capital markets was violated by interest rate caps and restrictions on the activities of savings and loans. Moreover, around the same time, inflation was raging, and other savings vehicles, offered by other types of institutions, were able to draw funds from the savings and loans by offering higher interest rates.

The government, aware of both the theories of economists about overregulation and the increasing financial difficulties of the savings and loans, then took action to "help" this industry. Caps on interest rates were lifted to help the saving and loans attract deposits. Moreover, barriers between different types of financial institutions began to be broken down, and as a result, savings and loans were allowed to enter many forms of lending other than home mortgages. Moreover, other institutions were allowed to enter the mortgage market, and mortgage bankers began to replace savings and loans as the primary originators of mortgages. As a result, a highly regulated industry with virtually guaranteed profitability and a narrow, fixed mission was changed into a dynamic, even freewheeling, part of the financial sector. 
Though some believe this outcome was a necessary solution to the hemorrhage of deposits of the 1970s, the cure came to have more serious and long-term consequences for the industry than the original disease, probably contributing to the ensuing crisis of the savings and loans.

In this period, efforts to create a mortgage-backed securities market were accelerated. The seeds of this movement had begun with the passage of the Housing and Urban Development Act of 1968 and further legislation in 1970, but greatly accelerated in the 1980s, which saw the passage of the Secondary Mortgage Market Enhancement Act.

As these reforms were undertaken, the system began to approach more closely the perfect capital markets of economic theory. By allowing the securitization of mortgages, the government helped turn the mortgage system into a truly national market. Whereas before, the availability of mortgages depended upon the wherewithal and cooperation of the local savings and loan, now mortgages could wind up in the hands of banks and investors all over the world, in the form of mortgage-backed securities. Interest rates were largely determined on these national markets, rather than set by local bankers or by the government. Colton notes that the share of mortgages funded through secondary markets has increased from 27 percent in 1984 to 59 percent in 2001 (2002). Moreover, savings and loans were able to make loans to a broader variety of lenders, theoretically allowing money to flow to its most productive use. They were free to bid for funds by raising their deposit rates, preventing a rationing of funds that might prevent worthy borrowers from receiving loans. The spread between the rates at which homeowners could borrow and lend diminished, another sign of a reduction in "imperfections."

These developments center on the growing importance of home equity loans beginning in the 1980s and gathering momentum to the present day. As banks and Freddie Mac and Fannie Mae began to stray from their original mission, they began to offer a larger array of services, and consumers obtained more and more second mortgages and home equity loans and lines of credit. In recent years, these loans, along with other forms of consumer credit, resulted in a situation in which debt imposed an increasing burden on individuals. In 2003 alone, households converted a total of $\$ 139$ billion of home equity into cash, and the number of mortgage refinancings increased from approximately 2.5 million in 2000 to over 15 million in 2003. Households used this cash for a variety of purposes. There is also a great deal of evidence that home equity loans were being used to buy investment properties.

Moderate-income citizens were not exempt from the trend, as financial institutions rushed to make "subprime," high-interest rate loans to the poor and those with low credit ratings 
(Office of Policy Development and Research, U.S. Department of Housing and Urban Development 2004). Another risky development was the increasing availability of "zero-down" and adjustable-rate mortgages, another legacy of deregulation. All of these developments were spurred in part by the supply side, with high-pressure mortgage brokers seeking large commissions (Anders 2005; Downey 2005). A once-sleepy industry, directed toward a specific social purpose, had given way to an industry in which profit, as opposed to homeownership and security, became increasingly important. Savings and loans shifted their attention away from the goods associated with profiting by homeownership and toward profit-making as such.

The reformers have not declared their job finished even now. In keeping with the desire to unify mortgages and other capital markets, many economists and policymakers would like to create a flat tax, eliminating the home mortgage interest deduction (Hall and Rabushka 1995). The government should not attempt to subsidize any form of borrowing, according to the views of many economists, since it prevents money from going to its most productive use. Here we see the use of the homogeneity thesis as a principle of government finance.

The "modernization" of the mortgage industry, and the future plans of the modernizers, flow in part from concerns of economic efficiency of the type expressed by neoclassical financial theory. The President's Commission on Housing explicitly advocated an expansion of secondary mortgage markets and a general deregulation of the industry specifically on the grounds of economic efficiency, and their proposals were largely enacted in the Secondary Mortgage Market Enhancement Act of 1984 (Colton 2002). It was no accident that one of the primary developers of modern neoclassical consumption theory was also one of the chief proponents of the elimination of the home mortgage interest tax deduction, a proposal that has recently resurfaced (Hall and Rabushka 1995). In that theory, as in other neoclassical theories, housing capital is no different than any other form of capital and does not deserve any special subsidy.

\section{IS THE BLUEPRINT BECOMING REALITY?}

Having surveyed the changes in housing finance in the United States, we now ask if consumption behavior has changed, and specifically, if the consumption theory of Friedman's permanent income hypothesis has proved prescient. We might call these views the "historically relative" homogeneity and liquidity hypotheses. Recall that in those theories all forms of 
nonhuman wealth are assumed to be liquid and fungible. Households base their consumption on the annuity value of their total nonhuman and human wealth, the latter referring to future earnings. An increment of 100 dollars in additional wealth will cause the same increase in overall consumption, regardless of the form that that wealth takes, from lottery winnings to pay raises to future earnings. It is assumed that all wealth, including home equity, is considered in the calculus of consumption decisions over time, as made possible by costless liquidation. This sort of theory contrasts with a Kaleckian approach in which workers' consumption is tied closely to its current income, or even a simplified Keynesian model with consumption dependent only on current income (Kalecki 1969; Keynes 1965 [1936]).

Liquidity constraints can cause the standard neoclassical theories to go astray, as most of their proponents will readily concede. Liquidity constraints imply that consumers would like to smooth their consumption by borrowing against future income but cannot do so because lenders are concerned about default risk. Hence, liquidity constraints can prevent the first-order condition, or Euler equation, of consumption theory from holding. Moreover, consumption may become more sensitive to shocks to current income than it would otherwise be in a permanent income model. According to neoclassical theory, anticipated future liquidity constraints can curtail consumption as easily as constraints that exist in the present (Romer 1996, p. 336). The possible effects of liquidity constraints have been verified in a number of studies long ago, which showed that the value of tangible assets had virtually no empirical relationship with consumer spending (Elliott 1980). Corner solutions pose many of the same problems as liquidity constraints for the validity of the theory.

But perhaps the new developments in mortgage finance have changed the importance of liquidity constraints, and hence the applicability of the simplest versions of consumption theory. ${ }^{5}$ In a new paper, Tamim Bayoumi and Hali Edison (2003) ask if "wealth is increasingly driving consumption." They argue that this might be the case if financial deregulation allowed consumers to obtain loans more easily, and especially to tap home equity. They find that countries with "market-based" financial systems have a larger propensity to consume out of wealth increases than those with bank-based systems and that the size of wealth effects on consumption has been rising over time, "probably reflecting financial deregulation." Aoki, Proudman, and Vlieghe (2002) argue along similar lines that liquidity constraints have been on the decline in the United Kingdom since deregulation began in the 1980s, and Bayoumi (1993) 
estimates that the percentage of British consumption determined by liquidity constraints fell from 60 percent to 30 percent as financial markets were deregulated. ${ }^{6}$

The impact on the overall economy, according to many authors, has been significant. Belsky and Prakken (2004, p. 2) estimate that housing wealth-related factors contributed 1.2 percentage points of four-quarter personal consumption expenditure growth in the third quarter of 2003, and estimates of the part of an additional dollar of housing wealth that is consumed tended to range from 6 to 8 cents (Belsky and Prakken 2004, p. 21). The liquidity thesis is almost surely more accurate now than it was 30 years ago. The homogeneity thesis, that all forms of wealth and debt are treated equally (to ongoing income and to other liquid forms of wealth) may be increasingly true, as well. Is Friedman turning out to be right, but just a little ahead of his time? If so, is this a welcome development, or do liquidity constraints serve some worthwhile function?

\section{THE UNIQUENESS OF HOUSING AMONG ALL GOODS}

In this paper, we propose to explain a lack of fungibility as part of a theory of the uniqueness of housing as a commodity documented before. It will constitute a normative and descriptive theory, appealing both to reason and to observation. Hence, it can be considered in some sense "rational." We explain the "shoulds" that help determine behavior. This will form a complement to behavioral theories that posit a lack of full neoclassical rationality (Shefrin and Thaler 1988). At the same time, this explanation constitutes an alternative to the neoclassical theories that have formed the "blueprint" for changes in financial markets - from securitization to interest rate deregulation to risky new mortgage instruments. It will suggest why current blueprints - the theory of perfect capital markets - may be failing to deliver their promised results, and why attempts to eliminate liquidity constraints might not be for the best.

If housing is a special good, which serves a social function, as argued above, then homes cannot easily be sold without profoundly influencing one's personal, social, and family life. The fact that housing is so deeply tied up with all aspects of human life means that people rationally treat their homes differently from other assets. This reluctance to trade away a home flows from several facts pointed out earlier. Homeowners take pride in the fact that their homes reflect their own efforts at improvement and decoration. They cannot readily "trade in" the social involvements connected with their homes, which include, for example, local government 
involvement and neighborly relationships, which can only be built up over time. In short, homeownership involves sunk emotional costs that cannot be rationally disregarded.

Of course, none of this implies that housing is not a commodity at all or that one should never sell one's house. It simply says that such a sale is a profound decision that affects the heart of one's existence and is usually not done unless there is a compelling reason, such as the need to move to take a new job or to obtain space for new children. Moreover, maintaining a home is not a universal good like love, but rather an individual and familial commitment that some may choose to avoid. This would be analogous to something like art: being an artist is a noble calling, but obviously similar in the sense that many elect not to become artists, focusing their attention on other, equally important and worthwhile pursuits.

There is evidence that most people understand that homes are special in a way that bonds are not. As mentioned before, many elderly people place a strong value on staying in the homes they have lived in for much of their lives, even when they would benefit from a cash-in of their home equity. Another piece of evidence is that people, at least until recently, have had a relatively low propensity to consume out of housing wealth (Elliott 1980). It is not just liquidity constraints, but deliberate choices to commit to a home that make housing wealth less accessible. One can think of this as psychic and social transactions costs to making use of home equity. This analysis applies to home equity loans and not just home sales, because people know they are putting their property at risk when they use their homes for collateral.

All of this leads to certain normative conclusions about the manner in which homes are to be valued - the proper "mode of valuation," in Anderson's parlance. ${ }^{7}$ Modes of valuation entail certain individual behaviors, as well as public policies. First, one aspect of valuation should be conservation. One does not rationally give up with equanimity one's home for another one with the same physical specifications, a clear contrast with ordinary commodities. At least once one has "broken in" a home and developed ties to the community, one should seek to maintain that home, barring major changes. This means in part not risking one's equity by taking out excessive home equity loans, and it may mean significant sacrifices of luxury and wealth. It also means that tradeoffs of housing consumption at the margin are often not considered among the consumers' options, for reasons beyond the "lumpiness" of the housing consumption decision. The Euler equation may not hold, for this reason. 
Second, one should strive to help maintain and improve the surrounding community, at least to some minimal degree. ${ }^{8}$ The goods of a community, as opposed to a home, come into play here. Though this is not the focus of this paper, it is easy to state some of the goods involved: safety, cohesion, good architecture, cleanliness, diversity, cultural life, and so on. As argued earlier, involvement in trying to achieve these social (community) ends tend to come by necessity along with the private goods of homeownership.

The normative imperatives of the goods of homeownership extend not only to the individual but also to the state. The relevant objectives are both that people obtain homes, and that they be able to stay in them. The state's obligation may be justified by certain benefits that accrue to society as a whole, not just the individual homeowner. If I am staying rooted in my community, I confer benefits on neighbors who also choose to stay, for they come to rely on my presence, just as I do theirs. Neighborhoods improve and the depth and quality of relationships grows. When the system works at its best, neglect of public goods is reduced. A system that breaks the bonds between neighborhoods and families and individuals reduces the sense of responsibility for civic goods that characterize good neighborhoods and cities and creates alienation. DiPasquale and Glaeser (1999) emphasize two types of investment encouraged by homeownership: social capital and local amenities. Social capital is the connections between neighbors that allow them to benefit from one another's presence in the community; this form of capital can be regarded as a common language among residents. Local amenities, on the other hand, are improvements such as gardens. A high level of social capital may allow me to benefit from the local amenities cultivated by neighbors. Both forms of capital, since they have external effects, are underproduced in a laissez-faire system.

Clearly, it is not only economic incentives that encourage homeowners to invest in their community involvements. As a symbol of being rooted in the community, a home encourages its residents to identify with the good of the community as a whole. Homes not only create economic incentives, but they change the "utility function" to favor certain activities. 9 "

Some empirical studies offer evidence that homeownership actually bears social benefits (DiPasquale and Glaeser 1999; Rohe, Van Zandt, and McCarthy 2002). Homeowners are 10 percent more likely to know their U.S. representative by name and are members of .25 more nonprofessional organizations than tenants (DiPasquale and Glaeser 1999, p. 356). When an instrumental variables technique was used to account for the fact that those who buy houses 
might be predisposed to be civically active independently of their actual homeownership, the results were strengthened.

The positive effects of homeownership apparently arise partly because homeowners are less mobile than renters and partly because homeownership encourages community involvement regardless of how long people stay in their houses (DiPasquale and Glaeser 1999).

That certain modes of valuation are appropriate for homes implies that certain public policies should be carried out, since a presumption exists that government should help homeowners value their properties and attain the social goods I have mentioned, in the absence of overriding considerations. It bears reemphasis that New Deal era policies such as guarantees of long-term mortgages help homeowners stay in their homes without risking bankruptcy. On the other hand, financial practices that subvert the end of homeownership or encourage putting home equity at risk should be discouraged. Moreover, the move to eliminate the home mortgage interest deduction should likely be opposed on the grounds that property ownership enables people to reap benefits that are not available to renters. The deduction also increases the production of local amenities and social capital, which have positive externalities. In general, the distinctness of the goods of homeownership warrants treating housing as a special good and justifies policies designed to favor that good. For example, it seems desirable for the government to ease the process of obtaining mortages for primary places of residence, but not to extend such favorable treatment to loans for second homes and investment properties. Moreover, there is nothing about the goods described in this paper that necessitates palaces; it seems reasonable to limit government subsidies to relatively modest home purchases and to make subsidies available to low- and moderate-income households. The cohesiveness of urban areas and the national "community" may be reduced by vast inequality in home wealth and in the quality of neighborhoods. It should be acknowledged that by favoring houses over other goods, the state might be paternalistically making choices on behalf of citizens, except for the fact that the benefits of homeownership are largely external to the home buyer.

Some draw slightly different lessons from the value of community involvement and homeownership. Though they recognize the benefits of stable communities, they emphasize the key role of private property and draw analogies to owners of capital. But clearly, the social lesson here does not imply that private property is paramount. The kinds of goods here involve the stability of neighborhoods, and free, unplanned development is notorious for trampling such goods. I cannot obtain the goods associated with a stable neighborhood by my individual 
economic actions. In an every-person-for-him or herself system, I have no incentive to stay in a declining neighborhood, because I know my neighbors, who also are not able to count on me, will be leaving. In a word, there is a problem of coordination that only a government can solve (Schelling 1978). When social thought encourages people to take social goods into consideration, the problem of coordination in the interest of social benefits will be lessened and will be appropriately dealt with by policymakers.

\section{EVALUATING A BLUEPRINT: A FINANCIAL CONSIDERATION}

Several themes need to be brought together now. We have seen that homes play a special role in the social and emotional lives of households. In the previous section, we indicated that this implies that it is rational (in a nonneoclassical sense) not to treat homes like any other form of wealth, such as bonds. However, we have also shown that economic theory suggests homes are indeed like other investments and that perfect markets should be developed that allow people to act as if they were, for example, by readily obtaining money for home equity. There is some evidence, we have shown, for the notion that these economic theories have acted as blueprints for recent policy developments and a normative guide for behavior. For this reason, the old barriers to exchanging houses like any other good are being broken down, and the theory is acting, perhaps, as a self-fulfilling prophecy. We pointed out in the beginning of the paper that

blueprints can be judged by whether they lead to confusion and a failure to realize the goods that are at stake. As markets are "perfected" and theory urges people to ignore the unique aspects of housing wealth, are we witnessing stumbling practice?

At this point, the paper must become speculative, as the outcomes of current trends have not become fully evident yet. First of all, there are some indications that consumption theory is not being borne out, even as its premise of high liquidity is becoming a reality. We believe that instead of agents faithfully executing their optimal plans, they are violating a key tenet of consumption theory: the "no-Ponzi," or transversality, condition (Obstfeld and Rogoff 1996, p. 64). This condition says that the total consumption path over a consumer's (sometimes infinite) life does not result in an ever-increasing (present value of) debt, with interest payments met through additional borrowing forever. Put another way, the no-Ponzi condition says that the present value of debt in the infinite future is zero. 
To fix ideas, an equation or two might help. The no-Ponzi condition is related to the agent's budget constraint

$\mathrm{C}_{\mathrm{t}}=(1+\mathrm{r}) \mathrm{B}_{\mathrm{t}}-\mathrm{B}_{\mathrm{t}+1}+\mathrm{Y}_{\mathrm{t}}$

Where $\mathrm{C}$ is consumption, $(1+\mathrm{r})$ is the (constant) gross interest rate, $\mathrm{B}$ is wealth, $\mathrm{Y}$ is income, and the subscripts indicate time periods. Wealth and income are in the same form as the consumption good. This equation holds at all time periods t. It simply says that I inherit a sum of money I saved last period, plus interest, and this sum is divided between current consumption and my saving for next period.

This equation is an identity, and aside from the fact that it only includes one type of asset (notably lacking money), it holds as an identity in the types of theories where it plays a role. When the aforementioned no-Ponzi condition is applied, however, we get a stronger statement of the budget constraint

$$
\sum_{s=t}^{\infty} 1 /(1+r)^{s-t} C_{s}=B_{t-1}+\sum_{s=t}^{\infty} 1 /(1+r)^{s-t} Y_{s}
$$

This equation relates the discounted present value of my future income (plus my initial wealth, $\mathrm{B}_{\mathrm{t}-1}$ ) to the discounted present value of my future consumption. Unlike the previous version of the budget constraint, this one is not an ex ante identity and assumes a great deal about the consumer's cognizance of and care for the future. It is important, since without it, the consumer's consumption is not constrained by his or her income, and consumption can be infinite.

Doubtless, consumer debt will not accumulate forever, but the current path of consumption in the United States may not be consistent with this fact; many analysts believe consumers are on an unsustainable trajectory, causing them to depart from their equilibrium consumption path. (It is beyond the scope of this paper to document that there is excessive household debt. See Papadimitriou, Chilcote, and Zezza 2006.) This phenomenon was studied in depth by Hyman Minsky $(1975,1986)$, who argued that what he called "Ponzi finance" was a likely outcome of a period of economic exuberance. ${ }^{10}$ The eventual result of this form of finance would be a widespread failure of agents to meet their payment commitments, leading to a crisis, 
and probably a recession. In essence, Minsky argued that economies regularly violated their non-Ponzi conditions, and that this phenomenon was a central part of the capitalist system. Lance Taylor's recent text contains a sustained critique of no-Ponzi conditions in neoclassical economics and the type of "trapeze dynamics" that are justified by these conditions (2004).

The ultimate reason for the failure of the no-Ponzi condition (and the related infinite horizon budget constraint shown above) is that people do not generally look to the infinite future and work backward from the necessity to stay solvent over the long term. Rather, they work forward from their current needs, usually keeping their debt under control by using simple rules of thumb, which may be more or less conservative. Their bankers do the same. The rules of thumb may grow so lax at times of complacent prosperity that Ponzi finance in fact exists (Minsky 1986).

This can be true partly because of fundamental uncertainty. In an uncertain world, overly optimistic or pessimistic views can go unchecked until an event occurs that reminds financial market participants of their vulnerability (Davidson 2002; Minsky 1975, 1986). But even if it is clear that a loan is overly risky, the urge to make a quick profit or commission may dominate all other thoughts. A loan officer needs to make as many loans as possible, and there is doubtless pressure to keep up with other loan officers.

It can be seen that Ponzi finance among households is being encouraged for a number of reasons, many relating to the purported need for freedom in choosing intertemporal tradeoffs. First of all, the evolving financial system, by pushing variable-rate mortgages, encourages a short-term view. Homebuyers are encouraged to take advantage of low variable rates, even though future increases in interest rates could make it impossible to service the debt. Some mortgages now feature negative amortization. Such features seem acceptable in good economic times, but may prove to have been very imprudent. It is largely a profit-driven industry that is driving the growth of potentially Ponzi mortgages (Anders 2005; Downey 2005). (Thus, the developments documented here do not represent a complete failure of agents to act in their selfinterest. But self-interest has brought perhaps unintended effects.) Also, people are eager to move into ever more expensive homes to take advantage of appreciation to the greatest possible extent. Low transaction costs ease this frenzied process. Moreover, there is some evidence that an increasing number of relatively well-off borrowers are using home-equity loans to make investments in properties other than main places of residence. (It is hard to disentangle the effects of easy mortgage finance from the run-up in real estate values; causality goes in both 
directions.) It is ironic that an economic theory that depends so heavily on long-term solvency (transversality) conditions to obtain coherent dynamics is breeding the conditions for what it may turn out is a period of widespread bankruptcies.

Economic theory has helped us forget that homes are special assets and commodities. In positing the homogeneity and liquidity theses, it has encouraged the notion that one should not treat home wealth with special care. It has encouraged freedom in making intertemporal tradeoffs by borrowing against and selling assets with equanimity. It has encouraged lenders and borrowers to see homeownership as just another form of "investment" and source of "consumption flows." More importantly, it has convinced policymakers to allow all types of borrowing against homes and homeowners to be tempted by the availability of risky but inexpensive finance, with insufficient concern for the long-term sustainability of homeownership. Policymakers have been distracted from the social goods associated with homeownership by the imperative to "free capital markets" and "give consumers more choices," both supremely important in the world of neoclassical economic theory. Investors are now free to sell mortgages like bushels of wheat, and homeowners are free to tap their home equity, and take perhaps more risks with their housing wealth than at any time since Roosevelt's reforms. If the analysis of this paper is correct, the costs of these ideas and policies will be measured in lost homes, declining neighborhoods, and a diminished sense of satisfaction among homeowners. Hence, neoclassical theory will have been discredited, not because it failed to match empirical reality, but because of its deleterious effect as a blueprint for reality. The attempt to create a world in the image of neoclassical capital theory, much like the attempt to create an economics in the image of physics, will be in doubt. 


\section{REFERENCES}

Akerlof, George. 2005. "Lecture Notes for Economics 202A. Lectures 13 and 14.” Berkeley, California.

Anders, George. 2005. “A Mortgage Salesman’s Pitch.” Wall Street Journal, July 20.

Anderson, Elizabeth S. 1993. Value in Ethics and Economics. Cambridge, Mass: Harvard University Press.

Aoki, Kosuke, James Proudman, and Gertjan Vlieghe. 2002. "Houses as Collateral: Has the Link Between House Prices and Consumption in the U.K. Changed?" Federal Reserve Bank of New York Economic Policy Review 8 (1): 163-77.

Bayoumi, Tamin. 1993. "Financial Deregulation and Consumption in the United Kingdom." Review of Economics and Statistics 75 (3): 536-540.

Bayoumi, Tamin, and Hali Edison. 2003. "Is Wealth Increasingly Driving Consumption?" De Nederlandsche Bank Staff Reports, No. 101.

Belsky, Eric, and Joel Prakken. 2004. "Housing Wealth Effects: Housing's Impact on Wealth Accumulation, Wealth Distribution, and Consumer Spending." Working Paper W04-13. Cambridge, Mass.: Joint Center for Housing Studies.

Bernanke, Ben S. 1983. "Nonmonetary Effects of the Financial Crisis in the Propagation of the Great Depression.” American Economic Review 73:3: 257-275.

Bernanke, Ben S., Mark Gertler, and Simon Gilchrist. 1999. "The Financial Accelerator in a Quantitative Business Cycle Framework.” In Handbook of Macroeconomics, Volume 1C, John B. Taylor and Michael Woodford, eds. New York: Elsevier.

Colton, Kent W. 2002. "Housing Finance in the United States: The Transformation of the U.S. Housing Finance System.” Working Paper. Cambridge, Mass.: Joint Center for Housing Studies.

Coşgel, Metin M., and Lanse Minkler. 2004. "Religious Identity and Consumption.” Review of Social Economy 62 (3): 340-350.

Davidson, Paul. 2002. Financial Markets, Money and the Real World. Northampton, Massachusetts: Edward Elgar.

DiPasquale, Denis, and Edward L. Glaeser. 1999. "Incentives and Social Capital: Are Homeowners Better Citizens?" Journal of Urban Economics 45 (2): 354-84.

Dolfsma, Wilfred. 2004. "Paradoxes of Modernist Consumption—Reading Fashions." Review of Social Economy 62 (3): 351-364.

Downey, Kirstin. 2005. “Market Driving Risky Mortgages.” Washington Post, June 3. 
Elliott, J. Walter. 1980. "Wealth and Wealth Proxies in a Permanent Income Model.” Quarterly Journal of Economics 95 (3): 509-535.

Fishback, Price V., William C. Horrace, and Shawn Kantor. 2001. "The Origins of Modern Housing Finance: The Impact of Federal Housing Programs during the Great Depression.” Working Paper. Tucson, Arizona: University of Arizona and NBER.

Fisher, Jonathan, David S. Johnson, Joseph Marchand, Timothy M. Smeeding, and Barbara Boyle Torrey. 2005. "The Retirement Consumption Conundrum: Evidence from a Consumption Survey.” Working Paper 2005-14. Chestnut Hill, Massachusetts: Center for Retirement Security at Boston College.

Friedman, Milton. 1957. A Theory of the Consumption Function. Princeton, N.J.: Princeton University Press.

Goffman, Erving. 1959. The Presentation of Self in Everyday Life. Garden City, New Jersey: Doubleday.

Hall, Robert E., and Alvin Rabushka. 1995. The Flat Tax. Second edition. Stanford, Califrornia: Hoover Institution Press.

Hannsgen, Greg. 2006. "Borrowing Alone: The Theory and Policy Implications of the Commodification of Finance. 2006. In Ethics and the Market: Insights from Social Economics, Betsy Jane Clary, Wilfred Dolfsma, and Deborah M. Figart, eds., London: Routledge, forthcoming.

Kalecki, Michal. 1969. Theory of Economic Dynamics: An Essay on Cyclical and Long-Run Changes in Capitalist Economy. New York: A. M. Kelley.

Kaserman, David L. 1978. "Evidence on the Decline of the FHA.” Journal of Money, Credit, and Banking 10 (2): 194-205.

Keister, Lisa A. 2002. "Financial Markets, Money, and Banking." Annual Review of Sociology: 28: 39-61.

Keynes, John Maynard. 1965 [1936]. The General Theory of Employment, Interest, and Money. New York: Harcourt, Brace, and World.

Lauria, D. 1976. "Wealth, Capital and Power: The Social Meaning of Home Ownership." Journal of Interdisciplinary History 7 (2): 261-282.

Leijonhufvud, Axel. 1968. On Keynesian Economics and the Economics of Keynes: A Study in Monetary Theory. New York: Oxford University Press.

McKinnon, Ronald I. 1973. Money and Capital in Economic Development. Washington, D.C.: Brookings Institution.

Minsky, Hyman P. 1975. John Maynard Keynes. New York: Columbia University Press. 
—. 1986. Stabilizing an Unstable Economy. New Haven, Conn.: Yale University Press.

Mirowski, Philip. 1989. More Heat Than Light: Economics as Social Physics, Physics as Nature's Economics. New York: Cambridge University Press.

Modigliani, Franco, and Richard Blumberg. 1954. "Utility Analysis and the Consumption Function: An Interpretation of Cross-Section Data." In Kenneth Kurihara, ed., Post Keynesian Economics. New Brunswick, N.J.: Rutgers University Press.

Obstfeld, Maurice, and Kenneth Rogoff. 1996. Foundations of International Macroeconomics. Cambridge, Massachusetts: MIT Press.

Office of Policy Development and Research, U.S. Department of Housing and Urban Development. 2004. "An Analysis of Mortgage Refinancing, 2001-2003." Washington, D.C.

Papadimitriou, Dimitri B., Edward Chilcote, and Gennaro Zezza. 2006. Are Housing Prices, Household Debt, and Growth Sustainable? Strategic Analysis. Annandale-on-Hudson, New York: The Levy Economics Institute.

Rohe, William M., Shannon Van Zandt, and George McCarthy. 2002. "Social Benefits and Costs of Homeownership." In Low-income Homeownership: Examining the Unexamined Goal, Nicolas Retsinas and Eric Belsky, eds., Cambridge, Mass.: Joint Center for Housing Studies; Washington, D.C.: Brookings Institution Press.

Romer, David. 1996. Advanced Macroeconomics. New York: McGraw Hill.

Schelling, Thomas. 1978. Micromotives and Macrobehavior. New York: W. W. Norton.

Schwartz, Barry. 1986. The Battle for Human Nature: Science, Morality, and Modern Life. New York: W. W. Norton.

Shefrin, Hersh M., and Richard H. Thaler. 1988. "The Behavioral Life-Cycle Hypothesis." Economic Inquiry 26 (4): 609-43.

Starr, Martha A. 2004. "Consumption, Identity, and the Sociocultural Constitution of 'Preferences': Reading Women's Magazines." Review of Social Economy 62 (3): 291305.

Stigler, George J., and Gary S. Becker. 1977. "De Gustibus Non Est Disputandum.” American Economic Review 67 (2): 76-90.

Stiglitz, Joseph E., and Andrew Weiss. 1981. "Credit Rationing in Markets with Imperfect Information.” American Economic Review: 71 (3): 393-410.

Taylor, Lance. 2004. Reconstructing Macroeconomics: Structuralist Proposals and Critiques of the Mainstream. Cambridge, Mass.: Harvard University Press. 
Thaler, Richard H. 1990. “Anomalies: Saving, Fungibility, and Mental Accounts.” Journal of Economic Perspectives 4 (1): 193-205.

Walzer, Michael. 1983. Spheres of Justice: A Defense of Pluralism and Equality. New York: Basic Books.

Wray, L. Randall. 2005. The Ownership Society: Social Security Is Only the Beginning. Public Policy Brief No. 82. Annandale-on-Hudson, N.Y.: The Levy Economics Institute. 


\section{NOTES}

${ }^{1}$ To be fair, Fisher was concerned with capital theory, and not merely consumption, in the sense that he did not take income as given, as have many consumption theorists since him. So, modern economists who cite Friedman and Modigliani and Blumberg are not being unreasonable in neglecting Fisher, the Austrian capital theorists, and other previous intertemporal economists. Consumption theory as distinct from intertemporal theory in general was largely stimulated by Keynes's work, which postdated the development of capital theory. Of course, modern textbooks and articles have freely combined Friedman and Modigliani and Blumberg's thought with "capital theory," in the form of production functions, and in fact, textbooks tend to misleadingly place consumption theory prior to neoclassical capital theory (such as it is), reversing the order in which the two fields historically developed.

${ }^{2}$ A related issue is whether homeowners are like capitalists because they hold a large asset. This claim is sometimes made, but convincing arguments have been marshaled on the other side (Lauria 1976; Wray 2005).

${ }^{3}$ This phenomenon has been used lately to explain why consumption appears to drop upon retirement. It turns out that when flows of consumption from homes are included, this drop may be smaller than previously thought (Fisher, Johnson, Marchand, Smeeding, and Torrey 2005).

${ }^{4}$ This use of a homogeneous form of value has been one strategy used to circumvent in capital theory problems associated with multiple produced means of production.

${ }^{5}$ This argument was first called to my attention by the late Bernard Saffran in about 1984.

${ }^{6}$ It is perhaps important not to overemphasize recent change. Transactions costs for liquidating a house are still much higher than for selling securities. But this also casts further doubt on the original homogeneity thesis.

${ }^{7}$ It is important to emphasize here that notions of the best life for community and the individual are what is at stake here. In all but the most cases, these do not amount to issues of right and wrong. Further, conceptions of the good forwarded here should make allowance for the uniqueness of individuals and the wide variety of their potential social contributions.

8 "Maintaining" or "preserving" a community and keeping its residents in place may seem at times conflict with the ideal of a racially and ethnically integrated society. Some may seek to deploy these terms to prevent social progress, but there is no reason why they should necessarily imply a continuation of economic and racial and ethnic segregation. A complete neglect of the need to maintain communities may be just as harmful to the objectives of integration as deliberate efforts to keep certain residents out. Introducing minority group members into predominantly white neighborhoods should be viewed as part and parcel of other activities that aim to increase the quality of residential areas.

${ }^{9}$ There is a long tradition in economics of attempting to explain differences in behavior by differences in constraints, rather than differences in objective functions (Stigler and Becker 1977). But in doing so, economists neglect an important function of policy: to encourage various commitments that have social and individual benefits.

${ }^{10}$ Note that Minsky's Ponzi finance primarily related to firm spending, rather than consumption. 